\title{
The capacity of the mature cow to lose and recover nitrogen and the significance of protein reserves
}

\author{
By R. PAQUAY, R. De BAERE and A. LOUSSE \\ Department of Animal Physiology, Faculty of Veterinary Medicine, \\ Cureghem, Io70 Brussels, Belgium
}

(Received I4 September 1970-Accepted ro May 1971)

\begin{abstract}
I. Six experiments were undertaken with mature, dry, non-pregnant cows to determine the capacity to lose and recover nitrogen and to study the significance of the labile and total protein reserves.

2. It was concluded that, without altering its ability to reach $\mathrm{N}$ equilibrium, the mature cow is able to store and lose large amounts of body proteins (certainly more than $5 \mathrm{~kg}$ ), when its $N$ and energy intakes are greatly varied. The repletion or depletion of protein reserves can occur over a long period of time (sometimes more than 5 months). Total protein reserves include a very labile part. This part is more rapidly lost during fasting than during feeding on low-protein diets; it can be used to meet temporarily the energy requirements of the animal.

3. $\mathrm{N}$ balance and body-weight gains were generally very well correlated.
\end{abstract}

More than a century ago, Voit (I866) concluded that the body of the well-nourished animal contains a store of labile proteins. The magnitude and significance of this store are still not clearly established. According to many authors (see Munro, I964), the amount of labile protein deposited in the body does not exceed $5 \%$ of the total body protein and this labile protein disappears within a few days when the subject is fasted, or fed on a protein-free diet. But Allison (1964), Allison, Wannemacher, Banks \& Wunner (1964) and Allison \& Wannemacher (1965) concluded that there was a larger protein reserve which can contribute to the maintenance of essential tissue structure. The protein reserve includes a very labile part.

Most of the previous experiments were undertaken with simple-stomached animals. The present paper describes the results of six experiments intended to determine the capacity of the mature, dry, non-pregnant cow to lose and regain nitrogen and to study the significance of labile and total protein reserves.

\section{EXPERIMENTAL}

Friesian cows were used and were kept in metabolism stalls allowing the separation of urine from faeces. One of the stalls was so arranged that the cow's weight was automatically recorded every hour.

Expt I. After being undernourished for 2 months, a 7 -year-old cow received $4 \mathrm{~kg}$ pea-straw hay and $4 \mathrm{~kg}$ ground barley each day for a period of 5 months. According to Kellner \& Becker (r 962 ), this ration provided $130 \%$ of the energy maintenance requirements of the cow. During another 5 -month period the ration was reduced by half ( $2 \mathrm{~kg}$ pea-straw hay and $2 \mathrm{~kg}$ barley). Urine and faeces were collected during 
seven $6 \mathrm{~d}$ periods with each ration. $\mathrm{N}$ excretion was also measured daily for the first $5 \mathrm{~d}$ of restricted feeding.

Expt 2. Two groups of four and three cows, 6-io years old and of almost the same body-weight, were so nourished during 3 months that the cows in one group became nearly I $30 \mathrm{~kg}$ heavier than those in the other. Later, all the cows were given the same ration ( $3 \mathrm{~kg}$ barley straw, $2 \mathrm{~kg}$ ground barley, $2 \mathrm{~kg}$ concentrated foods each day) during a 2-month period. Urine and faeces were collected three times during $6 \mathrm{~d}$ periods.

Expt 3. Three cows, 7-9 years old, received a winter ration of $3 \mathrm{~kg}$ hay and $3 \mathrm{~kg}$ ground barley for a month. Afterwards, grass, freshly cut each day, was given ad lib.; first-cut grass was given for 7 weeks and second-cut for 2 weeks. Urine and faeces were collected for $3 \mathrm{~d}$ every week. $\mathrm{N}$ excretion was also measured for the first $4 \mathrm{~d}$ of feeding on grass and during a $5 \mathrm{~d}$ fasting period after giving second-cut grass.

Expt 4. Three 8- to ro-year-old cows, fattened by prolonged copious feeding, received over a period of II weeks a half-maintenance ration (ration $A:{ }^{1} \cdot 5 \mathrm{~kg}$ hay, $\mathrm{I} \cdot 5 \mathrm{~kg}$ ground barley daily). Later the ration was modified (ration B: $2 \mathrm{~kg}$ hay, $4 \mathrm{~kg}$ barley daily) so that the maintenance requirements (Kellner \& Becker, I962) of the cows at the end of the period of restricted feeding were met; this ration was given for Io weeks. During the whole experiment, urine and faeces were collected for $3 \mathrm{~d}$ every week.

Expt 5. Nine diets were tested on a 9-year-old cow kept in the metabolism stall allowing the hourly recording of body-weight. The diets were composed of lucerne hay and concentrated food $(20.2 \%$ protein and $22.9 \%$ crude fibre) and lucerne and ground barley ( $15.3 \%$ protein and $2 \mathrm{I} \cdot 2 \%$ crude fibre) and wheat straw and ground barley ( $6.1 \%$ protein and $29.9 \%$ crude fibre) given at three levels of intake $(15,23$ and $3 \mathrm{I}$ Mcal daily). There was a $12 \mathrm{~d}$ collection period followed by a 3 or $5 \mathrm{~d}$ fasting period with each ration.

Expt 6. An I I-year-old cow was given $2 \mathrm{~kg}$ lucerne pellets and $2 \mathrm{~kg}$ concentrated food daily (ration A) and an 8-year-old cow was given $2 \mathrm{~kg}$ hay and $2 \mathrm{~kg}$ barley daily (ration $\mathrm{B}$ ). $\mathrm{N}$ balances were determined. Thereafter, both cows, for $5 \mathrm{~d}$, received $3.5 \mathrm{~kg}$ manioc starch and $0.5 \mathrm{~kg}$ barley straw, with a mineral supplement; $\mathrm{N}$ excretion was again measured daily.

Forages and barley were grown in the region of Brussels. The concentrated foods were supplied commercially and chosen for their protein content. During Expt 3, grass was cut every morning and kept in a cool room to reduce deterioration; samples were taken for analysis four times each week. During the experimental periods, faeces and urine were collected at 08.00 hours. The faeces were mixed with a power-stirrer.

$\mathrm{N}$ was determined by the Kjeldahl method, crude fibre by the Weende method (Association of Official Agricultural Chemists, 1965) and energy by direct calorimetry (De Baere, Paquay \& Lousse, I966).

When calculating the $\mathrm{N}$ balance we took into account the losses of $\mathrm{N}$ from the urine $(3.5 \%)$. The balance value will slightly overestimate the real balance since the $\mathrm{N}$ losses other than faecal and urinary (skin, hair) were not considered. These losses can be estimated as about $2 \mathrm{~g} / \mathrm{cow}$ daily (Agricultural Research Council, 1965). 
During Expts I and 5 the weight of the cow was recorded every hour; during the other experiments, the cows were weighed regularly before the morning feed. The rations were given in equal parts at 08.00 and 16.00 hours; during Expt 3 grass was available $a d l i b$. Water was always unrestricted.

\section{RESULTS}

Expt $\mathrm{I}$. The rations supplied $3 \mathrm{I}^{\circ} 4$ and ${ }_{15}{ }^{\circ} \mathrm{Mcal} / \mathrm{d}$, with an apparent digestibility, relatively constant, about 69 and $71 \%$ respectively. Crude protein and crude fibre contents were 19.5 and $23.7 \%$ in both rations.

Table I. Expt ז. Daily nitrogen balance of an individual cow

\begin{tabular}{|c|c|c|c|c|c|c|}
\hline Ration & Date & $\begin{array}{l}\text { Faecal } \\
\mathrm{N} \\
(\mathrm{g} / \mathrm{d})\end{array}$ & $\begin{array}{c}\text { Digestible } \\
\mathrm{N} \\
(\mathrm{g} / \mathrm{d})\end{array}$ & $\begin{array}{l}\text { N digesti- } \\
\text { bility } \\
(\%)\end{array}$ & $\begin{array}{l}\text { Urinary } \\
N \\
(\mathrm{~g} / \mathrm{d})\end{array}$ & $\begin{array}{c}\mathrm{N} \\
\text { balance } \\
(\mathrm{g} / \mathrm{d})\end{array}$ \\
\hline $\begin{array}{l}4 \mathrm{~kg} \text { pea-straw hay } \\
+4 \mathrm{~kg} \text { ground } \\
\text { barley }(123 \mathrm{~g} \mathrm{~N} / \mathrm{d})\end{array}$ & $\begin{array}{l}\text { 24-29 Oct. I964 } \\
\text { I6-2 I Nov. I964 } \\
\text { 5-10 Dec. I964 } \\
\text { 29 Dec. to } 6 \text { Jan. I } 965 \\
\text { 19-25 Jan. I965 } \\
\text { 9-15 Feb. I965 } \\
\text { 2-8 Mar. I965 }\end{array}$ & $\begin{array}{l}48 \\
48 \\
46 \\
49 \\
52 \\
56 \\
50\end{array}$ & $\begin{array}{l}75 \\
75 \\
77 \\
74 \\
71 \\
67 \\
73\end{array}$ & $\begin{array}{l}61 \\
61 \\
63 \\
60 \\
58 \\
54 \\
59\end{array}$ & $\begin{array}{l}41 \\
50 \\
55 \\
56 \\
55 \\
60 \\
66\end{array}$ & $\begin{array}{r}34 \\
25 \\
22 \\
18 \\
16 \\
7 \\
7\end{array}$ \\
\hline $\begin{array}{l}2 \mathrm{~kg} \text { pea-straw hay } \\
+2 \mathrm{~kg} \text { ground } \\
\text { barley }(6 \mathrm{I} \mathrm{g} \mathrm{N} / \mathrm{d})\end{array}$ & 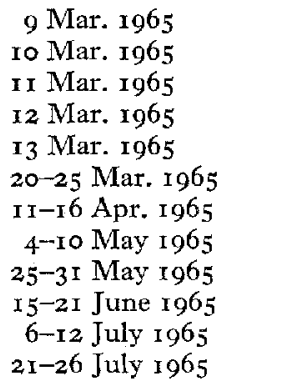 & $\begin{array}{l}40 \\
27 \\
34 \\
28 \\
25 \\
24 \\
27 \\
26 \\
22 \\
24 \\
25 \\
25\end{array}$ & $\begin{array}{l}21 \\
34 \\
27 \\
33 \\
36 \\
37 \\
34 \\
35 \\
39 \\
37 \\
36 \\
36\end{array}$ & $\begin{array}{l}34 \\
56 \\
44 \\
54 \\
59 \\
6 \mathrm{r} \\
56 \\
57 \\
64 \\
6 \mathrm{I} \\
59 \\
59\end{array}$ & $\begin{array}{l}66 \\
72 \\
66 \\
56 \\
54 \\
48 \\
45 \\
40 \\
42 \\
40 \\
38 \\
35\end{array}$ & $\begin{array}{l}-45 \\
-38 \\
-39 \\
-23 \\
-18 \\
-I I \\
-11 \\
-5 \\
-3 \\
-3 \\
-2 \\
-1\end{array}$ \\
\hline
\end{tabular}

The results for the $\mathrm{N}$ balance during the fourteen experimental periods are recorded in Table 1. During the whole experiment, the apparent digestibility of $\mathrm{N}$ showed only small variations, which are easily explained by the use of only one cow and the relatively short experimental periods $(6 \mathrm{~d})$.

With the copious ration, the urinary $\mathrm{N}$ increased from one experimental period to the next and $\mathrm{N}$ balance, high at the beginning, was progressively reduced and became near equilibrium at the end. The reduction of the ration by half was followed by a rapid decrease in faecal $\mathrm{N}$ excretion, but urinary $\mathrm{N}$ first increased and there was a large negative $\mathrm{N}$ balance. Later, urinary $\mathrm{N}$ diminished and balance was nearly at equilibrium during the last experimental period.

Fig. I shows the changes in the cow's body-weight; each point represents the mean body-weight during $3 \mathrm{~d}$. Weight gains were $36 \mathrm{~kg}$ during the first $5 \mathrm{~d}$ with the copious ration; later, the curve became inflected and, at the end of the period, a maximum seemed to be attained. Conversely, $26 \mathrm{~kg}$ were lost in $5 \mathrm{~d}$ with the restricted ration. 
Later, the losses became less, and during the last week the weight seemed to become stable.

Expt 2. At the beginning of the pre-experimental period, the mean body-weights of the cows were $58 \mathrm{I} \mathrm{kg}$ in group A and 572 in group $B ; 3$ months later, after very different rations, the mean weights were 524 and $648 \mathrm{~kg}$ respectively.

The experimental ration supplied $30.7 \mathrm{Mcal} / \mathrm{d}$, with a slightly higher digestibility in group $\mathrm{B}(6 \mathrm{r} \%)$ than in group $\mathrm{A}(57 \%)$. N content was $9.85 \%$, crude fibre content $26 \cdot 5 \%$.

The results for $\mathrm{N}$ balance are recorded in Table 2. Digestibility of $\mathrm{N}$ was almost

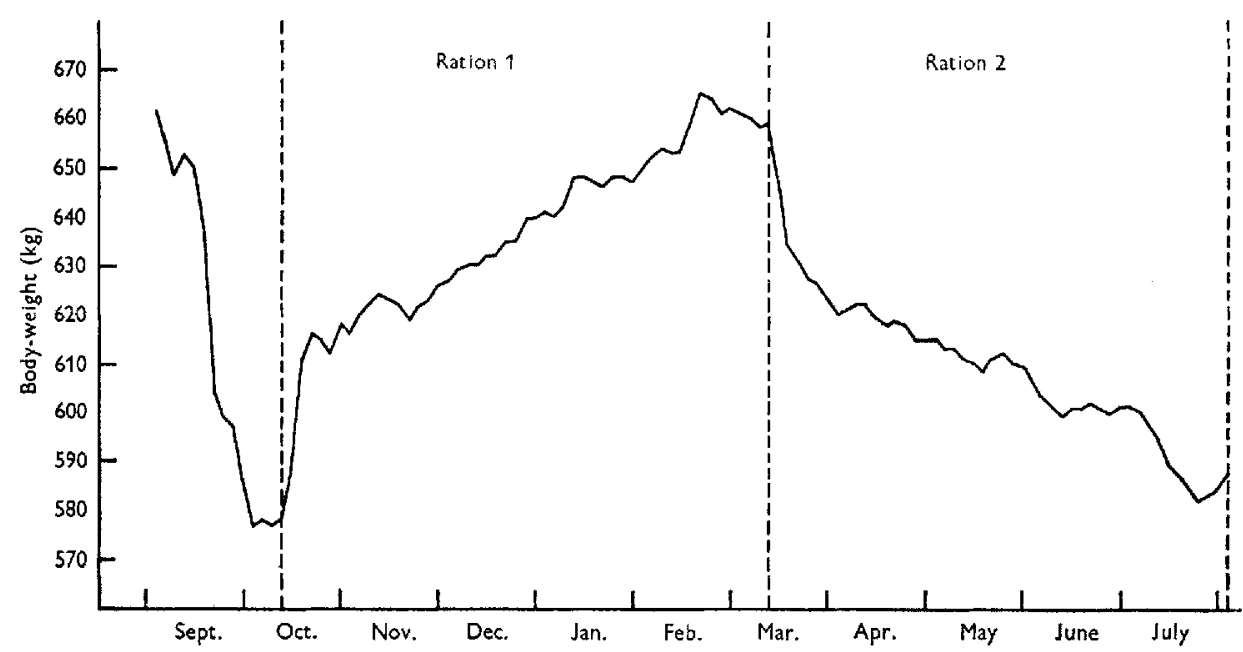

Fig. I. Change in the body-weight of the undernourished cow studied in Expt I. Ration I: $4 \mathrm{~kg}$ pea-straw hay $+4 \mathrm{~kg}$ ground barley. Ration $2: 2 \mathrm{~kg}$ pea-straw hay $+2 \mathrm{~kg}$ ground barley.

Table 2. Expt 2. Mean daily nitrogen balance and body-weight of cows receiving a ration of straw, barley and concentrates which provided $97 \mathrm{~g} N$ daily

\begin{tabular}{|c|c|c|c|c|c|c|c|}
\hline Group & Date $(1967)$ & $\begin{array}{c}\text { Faecal } \\
\text { N } \\
(\mathrm{g} / \mathrm{d})\end{array}$ & $\begin{array}{c}\text { Digestible } \\
\underset{(\mathrm{g} / \mathrm{d})}{ }\end{array}$ & $\begin{array}{c}N \text { digesti- } \\
\text { bility } \\
(\%)\end{array}$ & $\begin{array}{c}\text { Urinary } \\
N \\
(\mathrm{~g} / \mathrm{d})\end{array}$ & $\begin{array}{c}\mathrm{N} \\
\text { balance } \\
(\mathrm{g} / \mathrm{d})\end{array}$ & $\begin{array}{c}\text { Body-w } \\
\text { (kg) }\end{array}$ \\
\hline \multirow[t]{8}{*}{ A (four cows) } & I9 May & - & 一 & - & - & 一 & 524 \\
\hline & 3o May & - & - & - & - & - & $53^{\circ}$ \\
\hline & 3I May-6 June & $3^{8}$ & 59 & $6 \mathrm{x} \pm 0.58$ & $4^{8} \pm \mathbf{I} \cdot 55$ & II $\pm I \cdot I I$ & \\
\hline & I4 June & - & - & - & - & - & 539 \\
\hline & 18-23 June & $3^{8}$ & 59 & $61 \pm 0.25$ & $40 \pm 0.70$ & $19 \pm 0.87$ & - \\
\hline & I July & - & - & - & - & - & 545 \\
\hline & 9-I4 July & 37 & 60 & $62 \pm \mathrm{I} \cdot 03$ & $42 \pm I \cdot I I$ & $\mathbf{I}+ \pm \mathbf{I} \cdot 08$ & - \\
\hline & I4 July & - & 一 & - & - & - & 557 \\
\hline \multirow[t]{7}{*}{ B (three cows) } & I9 May & - & - & - & - & - & 648 \\
\hline & 3o May & - & 一 & - & - & - & 618 \\
\hline & 3I May-6 June & 36 & $6 \mathrm{I}$ & $63 \pm x \cdot 86$ & $64 \pm 5 \cdot 13$ & $-3+6.06$ & - \\
\hline & I 4 June & - & - & - & - & - & 612 \\
\hline & I8-23 June & 38 & 59 & $6 \mathrm{x} \pm \mathrm{x} \cdot 77$ & $5^{2} \pm 2 \cdot 89$ & $7 \pm 2 \cdot 19$ & $\bar{x}$ \\
\hline & 9-I4 July & $\overline{3^{6}}$ & $\overline{6 r}$ & $63 \pm I \cdot 20$ & $49 \pm 2 \cdot 89$ & $12 \pm 3.00$ & 612 \\
\hline & I4 July & 一 & - & - & - & - & 611 \\
\hline
\end{tabular}


the same in both groups and, unlike urine losses, it varied little. Cows of group A stored $\mathrm{N}$ during the whole experiment; cows of group $\mathrm{B}$ lost $\mathrm{N}$ at the beginning. Between the two groups, the differences were $\mathrm{I} 4 \mathrm{~g}$ for daily $\mathrm{N}$ balance during the first experimental period, II $\mathrm{g}$ during the second period and only $6 \mathrm{~g}$ during the last; the two groups thus drew near to one another. The same trends were found for body-weight.

Expt 3. The winter ration used supplied 23.7 Mcal daily with an energy digestibility of $75.7 \%$; the $\mathrm{N}$ content was $8.85 \%$ and the crude fibre content $19.8 \%$.

Table 3. Expt 3. Mean intake of freshly cut grass by three cows and the composition of the grass

\begin{tabular}{|c|c|c|c|c|c|}
\hline & Date (1968) & $\begin{array}{l}\text { Grass } \\
\text { intake } \\
(\mathrm{kg} / \mathrm{d})\end{array}$ & $\begin{array}{c}\text { Dry-matter } \\
\text { intake } \\
(\mathrm{kg} / \mathrm{d})\end{array}$ & $\begin{array}{l}\text { Protein } \\
\text { content } \\
\text { (\% of dry } \\
\text { matter) }\end{array}$ & $\begin{array}{c}\text { Crude fibre } \\
\text { content } \\
\text { (\% of dry } \\
\text { matter) }\end{array}$ \\
\hline First-cut grass & $\begin{array}{r}\text { I May } \\
20 \text { May } \\
27 \text { May } \\
3 \text { June } \\
\text { Io June } \\
\text { I7 June }\end{array}$ & $\begin{array}{l}60 \cdot 6 \\
64 \cdot 0 \\
63 \cdot 4 \\
58 \cdot 8 \\
54 \cdot 3 \\
58 \cdot 4\end{array}$ & $\begin{array}{r}8.9 \\
10.5 \\
11.4 \\
9.8 \\
10.7 \\
10.5\end{array}$ & $\begin{array}{r}17 \cdot 9 \\
14.6 \\
12 \cdot 1 \\
9 \cdot 5 \\
8.9 \\
8 \cdot 8\end{array}$ & $\begin{array}{l}20 \cdot 5 \\
21 \cdot 3 \\
22 \cdot 3 \\
24 \cdot 3 \\
22 \cdot 5 \\
25 \cdot 1\end{array}$ \\
\hline Second-cut grass & $\begin{array}{l}24 \text { June } \\
\text { I July }\end{array}$ & $\begin{array}{l}62 \cdot 3 \\
55 \cdot 0\end{array}$ & $\begin{array}{r}10 \cdot 0 \\
8 \cdot 7\end{array}$ & $\begin{array}{l}12.4 \\
\mathrm{I} 4.8\end{array}$ & $\begin{array}{l}24 \cdot 6 \\
22 \cdot 3\end{array}$ \\
\hline
\end{tabular}

The amounts of grass eaten and its composition are given in Table 3 . The values obtained for $\mathrm{N}$ balance are recorded in Table 4 . With the winter ration, $\mathrm{N}$ balance was near equilibrium and body-weight remained unchanged. A very high intake of $\mathrm{N}$ was recorded with unrestricted consumption of grass. The adjustment of faecal $\mathrm{N}$ was slow, whereas the uinary excretion increased abruptly as early as the Ist day. At first a large $N$ repletion occurred with first-cut grass; later, the balance diminished rapidly to a value near zero; renewed storage of protein occurred with the second-cut grass, owing to increased $\mathrm{N}$ intake.

When changing the cows from the winter ration to first-cut grass and from first-cut to second-cut grass, transient weight losses were recorded; these excepted, the changes in body-weight paralleled those in $\mathrm{N}$ balance.

The values obtained for $\mathrm{N}$ balance during the fasting period are given in Table 5 . Faecal $\mathrm{N}$ excretion decreased rapidly, whereas after $5 \mathrm{~d}$ urinary $\mathrm{N}$ losses remained large; $575 \mathrm{~g} \mathrm{~N}$, corresponding to $3.5 \mathrm{~kg}$ protein, were lost during the $5 \mathrm{~d}$. Body-weight losses were $46 \mathrm{~kg}$.

Expt 4. The variations in the $\mathrm{N}$ balance and in the body-weight of the cows during the 7 months preceding this experiment had been recorded. After being given a ration of $3 \mathrm{~kg}$ hay and $3 \mathrm{~kg}$ barley daily, ensuring $\mathrm{N}$ and weight equilibrium $(580 \mathrm{~kg})$, the three cows were given grass, hay and barley ad lib. for 6 months. At the end of this period, body-weight became stable $\left(65^{8} \mathrm{~kg}\right)$ and $\mathrm{N}$ balance was at equilibrium after large protein reserves were deposited.

Rations A and B supplied 10.9 and $2 \mathrm{I} .5 \mathrm{Mcal}$ daily; the protein and crude fibre contents were 10.1 and $17.4 \%$ respectively in ration $A, 9.8$ and $13.1 \%$ in ration $B$. 


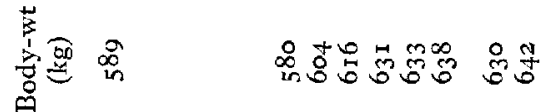

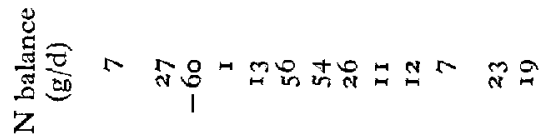
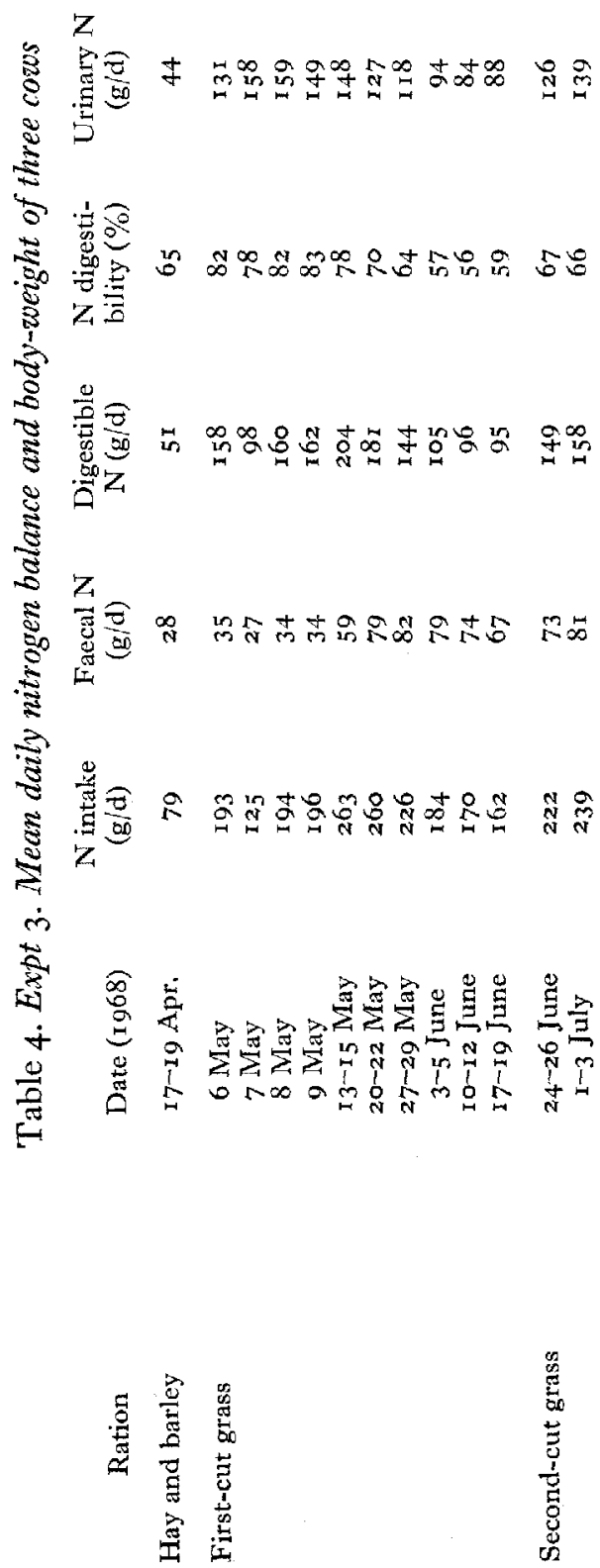
The results for $\mathrm{N}$ balance during the twenty experimental periods are recorded in Table 6. With ration $\mathrm{A}, \mathrm{N}$ digestibility was low during the ist week as a consequence of the previous diet; later, though many variations occurred, these were certainly due to the shortness of the experimental periods $(3 \mathrm{~d})$ and $\mathrm{N}$ digestibility can thus be considered to have been fairly constant. There was a large negative $\mathrm{N}$ balance during the Ist week in which ration $\mathrm{A}$ was given; later, the losses were smaller and equilibrium was almost obtained; changes in body-weight followed the same pattern. At first ration $\mathrm{B}$ allowed large $\mathrm{N}$ and weight gains; a diminution occurred later but, even at the end of the period, equilibrium was not approached.

\section{Table 5. Expt 3. Mean daily nitrogen balance and body-weight of three cows preceding and during a fasting period}

$\begin{array}{lcccc} & \begin{array}{c}\text { Faecal N } \\ (\mathrm{g} / \mathrm{d})\end{array} & \begin{array}{c}\text { Urinary N } \\ (\mathrm{g} / \mathrm{d})\end{array} & \begin{array}{c}\mathrm{N} \text { balance } \\ (\mathrm{g} / \mathrm{d})\end{array} & \begin{array}{c}\text { Body-wt } \\ (\mathrm{kg})\end{array} \\ \text { Week preceding fasting } & 8 \mathrm{I} & 139 & \mathrm{I9} & 642 \\ \text { Fasting day 1 } & 49 & \mathrm{II8} & -165 & - \\ \text { Fasting day 2 } & 23 & \mathrm{II2} & -133 & 6 \mathrm{I2} \\ \text { Fasting day 3 } & 17 & 98 & -\mathrm{II} 4 & - \\ \text { Fasting day 4 } & 12 & 67 & -79 & 60 \mathrm{r} \\ \text { Fasting day 5 } & 10 & 70 & -80 & 596\end{array}$

Expt 5. The results for $\mathrm{N}$ balance are recorded in Table 7. Fasting always induced a rapid fall in the excretion of $\mathrm{N}$ in the faeces. This fall was greater the higher the level of $\mathrm{N}$ in the faeces immediately before fasting. On the other hand, urinary $\mathrm{N}$ losses usually increased; with the last ration, urinary $\mathrm{N}$ was $60 \%$ higher on the 5 th day of fasting than during the preceding experimental period. Total $N$ losses during the fasting periods were related to the $\mathrm{N}$ intake before fasting. With the second ration, $375 \mathrm{~g} \mathrm{~N}(2 \cdot 3 \mathrm{~kg}$ crude protein) were lost in $3 \mathrm{~d}$.

Expt 6. The results for $\mathrm{N}$ balance are given in Table 8. With the low-protein diet, faecal $\mathrm{N}$ excretion remained rather high and even temporarily increased. On the other hand, from the Ist day, urinary $\mathrm{N}$ excretion rapidly diminished. Total $\mathrm{N}$ losses were lower than during fasting (Expt 5).

\section{DISCUSSION}

Since Voit (r866) demonstrated that an adult animal is able to store protein, most authors (see Munro, I964) have concluded that the capacity for repletion and depletion of $\mathrm{N}$ is low. On the other hand, recent experiments undertaken with men, rats and dogs (Allison, 1964; Allison et al. 1964; Allison \& Wannemacher, 1965; Gopalan \& Nasaringa Rao, I966) showed that the protein reserves may amount to as much as $20 \%$ or even $25 \%$ of body protein.

In ruminants, few studies have been made on this subject. In previous work (Paquay, De Baere \& Lousse, 1967; Paquay, 1968) it appeared that the mature, dry, nonpregnant cow has a large capacity to lose and recover $\mathrm{N}$. The same conclusion can be drawn here; depending on whether the cow has been previously undernourished, fattened or maintained in equilibrium, it is able under extremely variable nutritional conditions to store and lose large amounts of $\mathrm{N}$. Our results indicate that the values 


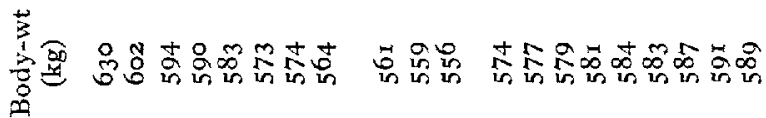
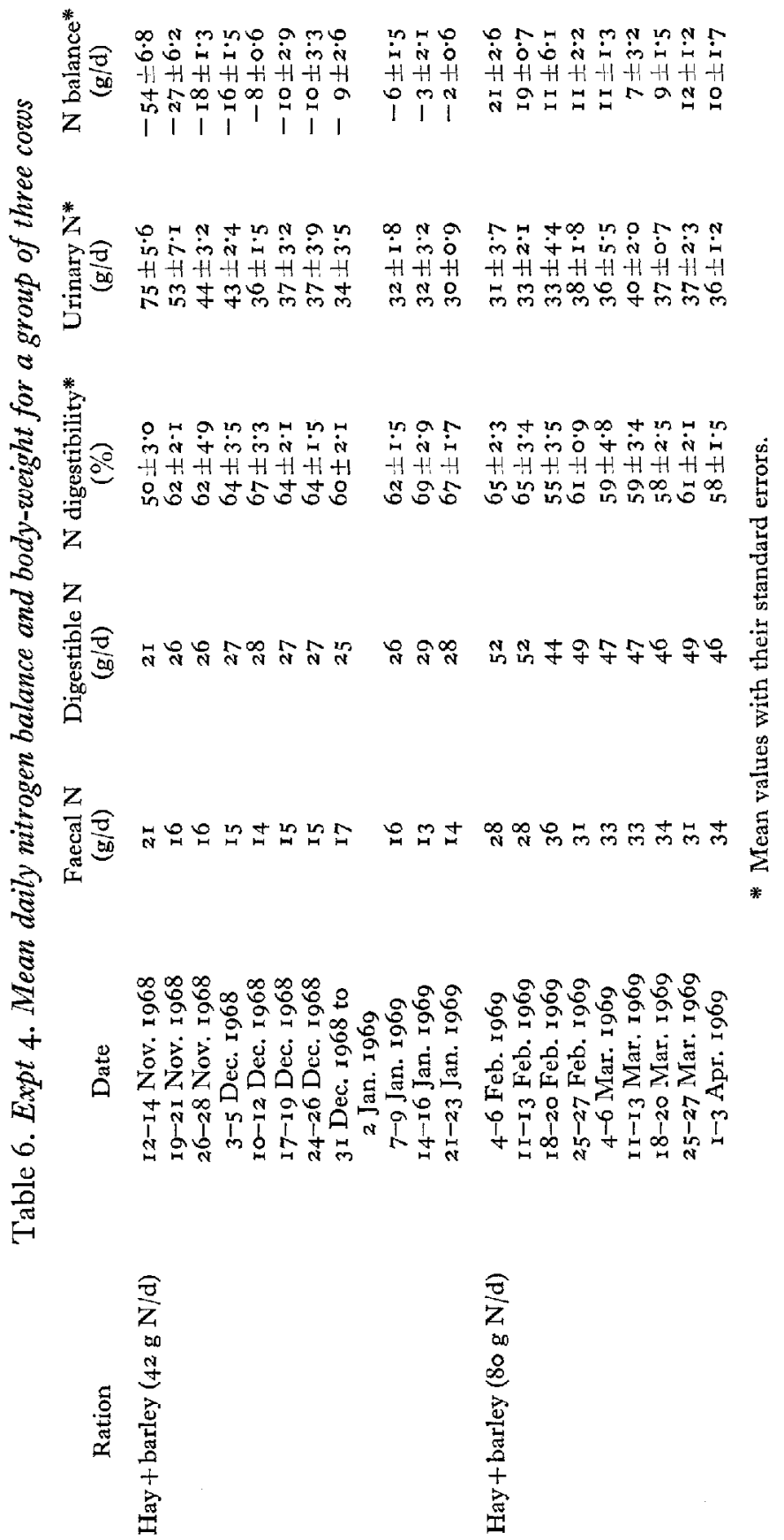
given by Allison (1964) for rats and dogs (20-25\% of body $N$ ) may be approached, if not attained, by the cow, even with rations which allow the cow to reach $\mathrm{N}$ equilibrium. Even when considering that the balance values given in Table $I$ were slightly overestimated since they do not take into account the daily loss of some $2 \mathrm{~g} \mathrm{~N}$ in hair and

Table 7. Expt 5. Nitrogen balance and body-weight of an individual cow during the $\mathrm{I} 2 d$ periods preceding fasting and on successive days of fasting

\begin{tabular}{|c|c|c|c|c|c|}
\hline Previous ration & & $\begin{array}{l}\text { Faecal N } \\
\qquad(\mathrm{g} / \mathrm{d})\end{array}$ & $\begin{array}{l}\text { Urinary } N \\
(\mathrm{~g} / \mathrm{d})\end{array}$ & $\begin{array}{l}\text { N balance } \\
(\mathrm{g} / \mathrm{d})\end{array}$ & $\begin{array}{c}\text { Body-wt } \\
\text { (kg) }\end{array}$ \\
\hline $\begin{array}{l}2 \mathrm{~kg} \text { lucerne }+2 \mathrm{~kg} \\
\text { concentrate foods } \\
\text { (I } 5 \mathrm{~g} \mathrm{~N} / \mathrm{d} \text { ) }\end{array}$ & $\begin{array}{l}\text { Not fasting } \\
\text { Fasting day I } \\
\text { Fasting day } 2 \\
\text { Fasting day } 3\end{array}$ & $\begin{array}{r}2 \mathbf{I} \\
22 \\
\mathbf{I I} \\
8\end{array}$ & $\begin{array}{l}78 \\
83 \\
67 \\
53\end{array}$ & $\begin{array}{r}16 \\
-105 \\
-78 \\
-61\end{array}$ & $\begin{array}{l}583 \\
575 \\
567 \\
562\end{array}$ \\
\hline $\begin{array}{l}3 \mathrm{~kg} \text { lucerne }+3 \mathrm{~kg} \\
\text { concentrate foods } \\
(172 \mathrm{~g} \mathrm{~N} / \mathrm{d})\end{array}$ & $\begin{array}{l}\text { Not fasting } \\
\text { Fasting day I } \\
\text { Fasting day } 2 \\
\text { Fasting day } 3\end{array}$ & $\begin{array}{r}35 \\
28 \\
19 \\
7\end{array}$ & $\begin{array}{r}100 \\
122 \\
104 \\
88\end{array}$ & $\begin{array}{r}37 \\
-150 \\
-123 \\
-95\end{array}$ & $\begin{array}{l}592 \\
586 \\
574 \\
569\end{array}$ \\
\hline $\begin{array}{l}4 \mathrm{~kg} \text { lucerne }+4 \mathrm{~kg} \\
\text { concentrate foods } \\
(229 \mathrm{~g} \mathrm{~N} / \mathrm{d})\end{array}$ & $\begin{array}{l}\text { Not fasting } \\
\text { Fasting day I } \\
\text { Fasting day } 2\end{array}$ & $\begin{array}{l}58 \\
40 \\
13\end{array}$ & $\begin{array}{r}127 \\
116 \\
93\end{array}$ & $\begin{array}{r}44 \\
-156 \\
-106\end{array}$ & $\begin{array}{l}607 \\
600 \\
596\end{array}$ \\
\hline $\begin{array}{r}2 \mathrm{~kg} \text { lucerne }+2 \mathrm{~kg} \\
\text { barley }(86 \mathrm{~g} \mathrm{~N} / \mathrm{d})\end{array}$ & $\begin{array}{l}\text { Not fasting } \\
\text { Fasting day } \mathrm{I} \\
\text { Fasting day } 2 \\
\text { Fasting day } 3\end{array}$ & $\begin{array}{r}20 \\
19 \\
8 \\
6\end{array}$ & $\begin{array}{l}50 \\
52 \\
79 \\
41\end{array}$ & $\begin{array}{r}16 \\
-71 \\
-87 \\
-47\end{array}$ & $\begin{array}{l}558 \\
556 \\
549 \\
544\end{array}$ \\
\hline $\begin{array}{c}3 \mathrm{~kg} \text { lucerne }+3 \mathrm{~kg} \\
\text { barley }(\mathrm{r} 29 \mathrm{~g} \mathrm{~N} / \mathrm{d})\end{array}$ & $\begin{array}{l}\text { Not fasting } \\
\text { Fasting day I } \\
\text { Fasting day } 2 \\
\text { Fasting day } 3\end{array}$ & $\begin{array}{r}34 \\
28 \\
12 \\
8\end{array}$ & $\begin{array}{l}71 \\
67 \\
60 \\
47\end{array}$ & $\begin{array}{r}24 \\
-95 \\
-72 \\
-55\end{array}$ & $\begin{array}{l}575 \\
571 \\
562 \\
555\end{array}$ \\
\hline $\begin{array}{l}4 \mathrm{~kg} \text { lucerne }+4 \mathrm{~kg} \\
\text { barley }(\mathrm{r} 72 \mathrm{~g} N / \mathrm{d})\end{array}$ & $\begin{array}{l}\text { Not fasting } \\
\text { Fasting day I } \\
\text { Fasting day } 2 \\
\text { Fasting day } 3\end{array}$ & $\begin{array}{l}49 \\
35 \\
18 \\
12\end{array}$ & $\begin{array}{r}83 \\
100 \\
85 \\
69\end{array}$ & $\begin{array}{r}40 \\
-+35 \\
-103 \\
-81\end{array}$ & $\begin{array}{l}603 \\
599 \\
585 \\
576\end{array}$ \\
\hline $\begin{array}{r}2 \cdot 2 \mathrm{~kg} \text { straw }+2 \mathrm{~kg} \\
\text { barley }(37 \mathrm{~g} \mathrm{~N} / \mathrm{d})\end{array}$ & $\begin{array}{l}\text { Not fasting } \\
\text { Fasting day I } \\
\text { Fasting day } 2 \\
\text { Fasting day } 3\end{array}$ & $\begin{array}{r}20 \\
20 \\
12 \\
9\end{array}$ & $\begin{array}{l}20 \\
28 \\
55 \\
25\end{array}$ & $\begin{array}{l}-3 \\
-48 \\
-67 \\
-34\end{array}$ & $\begin{array}{l}553 \\
554 \\
545 \\
537\end{array}$ \\
\hline $\begin{array}{r}3.3 \mathrm{~kg} \text { straw }+3 \mathrm{~kg} \\
\text { barley }(55 \mathrm{~g} \mathrm{~N} / \mathrm{d})\end{array}$ & $\begin{array}{l}\text { Not fasting } \\
\text { Fasting day I } \\
\text { Fasting day } 2 \\
\text { Fasting day } 3\end{array}$ & $\begin{array}{l}36 \\
32 \\
18 \\
14\end{array}$ & $\begin{array}{l}23 \\
25 \\
31 \\
3^{8}\end{array}$ & $\begin{array}{r}-4 \\
-57 \\
-49 \\
-52\end{array}$ & $\begin{array}{l}564 \\
559 \\
548 \\
539\end{array}$ \\
\hline $\begin{array}{r}4.4 \mathrm{~kg} \text { straw }+4 \mathrm{~kg} \\
\text { barley }(73 \mathrm{~g} \mathrm{~N} / \mathrm{d})\end{array}$ & $\begin{array}{l}\text { Not fasting } \\
\text { Fasting day I } \\
\text { Fasting day } 2 \\
\text { Fasting day } 3 \\
\text { Fasting day } 4 \\
\text { Fasting day } 5\end{array}$ & $\begin{array}{r}44 \\
45 \\
18 \\
15 \\
14 \\
9\end{array}$ & $\begin{array}{l}25 \\
23 \\
34 \\
44 \\
40 \\
40\end{array}$ & $\begin{array}{r}4 \\
-68 \\
-52 \\
-59 \\
-54 \\
-49\end{array}$ & $\begin{array}{l}594 \\
591 \\
573 \\
558 \\
547 \\
538\end{array}$ \\
\hline
\end{tabular}

skin secretions, these values allow us to conclude that certainly ${ }_{5} \mathrm{~kg}$ of protein or of corresponding non-protein $\mathrm{N}$ were deposited with the copious ration during Expt $\mathrm{I}$. This figure was obtained as follows. The copious ration was given from I $3_{3}$ October I964 up to $8 \mathrm{March} 1965$. We considered that from 8 October up to 29 October, the end of the ist experimental period, the $\mathrm{N}$ balance was $34 \mathrm{~g} / \mathrm{d}$; it was $25 \mathrm{~g} / \mathrm{d}$ from 30 October up to 21 November, the end of the 2nd experimental period. For the whole period, we obtained a total retention of about $2 \cdot 7 \mathrm{~kg} \mathrm{~N}$, nearly $I_{7} \mathrm{~kg}$ protein. The 
period of time necessary to reach $\mathrm{N}$ equilibrium may be very long, e.g. more than 5 months in Expt 1 .

The studies of the changes in body composition when the nature of the ration varies is also interesting. As in the pig (Robinson, I965), chicken (Fisher, Grun, Shapiro \& Ashley, 1964) and lamb (Walker \& Cook, 1967), the percentage of protein in the carcass increases as the protein content of the diet increases. Seebeck \& Tulloh (I969)

Table 8. Expt 6. Changes in the daily nitrogen balance and body-zeight of two cows when given a low- $N$ diet

\begin{tabular}{|c|c|c|c|c|c|}
\hline Ration & Date (1970) & $\begin{array}{c}\text { Faecal N } \\
\text { (g/d) }\end{array}$ & $\begin{array}{c}\text { Urinary } N \\
(\mathrm{~g} / \mathrm{d})\end{array}$ & $\begin{array}{l}\text { N balance } \\
\text { (g/d) }\end{array}$ & $\begin{array}{c}\text { Body-wt } \\
\text { (kg) }\end{array}$ \\
\hline $\begin{array}{l}2 \mathrm{~kg} \text { lucerne pellets }+2 \mathrm{~kg} \\
\text { concentrated foods } \\
(127 \mathrm{~g} \mathrm{~N} / \mathrm{d})\end{array}$ & 4-6 Feb. & 25 & 78 & 24 & 625 \\
\hline $\begin{array}{l}3.5 \mathrm{~kg} \text { manioc starch }+ \\
0.5 \mathrm{~kg} \text { barley straw } \\
(3 \mathrm{~g} \mathrm{~N} / \mathrm{d})\end{array}$ & $\begin{array}{l}9 \text { Feb. } \\
\text { Io Feb. } \\
\text { I I Feb. } \\
\text { I } 2 \text { Feb. } \\
\text { I } 3 \text { Feb. }\end{array}$ & $\begin{array}{l}39 \\
29 \\
14 \\
15 \\
14\end{array}$ & $\begin{array}{l}61 \\
26 \\
21 \\
23 \\
18\end{array}$ & $\begin{array}{l}-97 \\
-52 \\
-32 \\
-35 \\
-29\end{array}$ & $\begin{array}{l}616 \\
608 \\
598\end{array}$ \\
\hline $\begin{array}{l}2 \mathrm{~kg} \text { hay }+2 \mathrm{~kg} \text { barley } \\
(66 \mathrm{~g} \mathrm{~N} / \mathrm{d})\end{array}$ & 4-6 Feb. & $2 \mathrm{I}$ & 50 & -5 & 598 \\
\hline $\begin{array}{l}3.5 \mathrm{~kg} \text { manioc starch }+ \\
0.5 \mathrm{~kg} \text { barley straw } \\
(3 \mathrm{~g} \mathrm{~N} / \mathrm{d})\end{array}$ & $\begin{array}{l}9 \text { Feb. } \\
\text { 10 Feb. } \\
\text { I I Feb. } \\
\text { I } 2 \text { Feb. } \\
\text { I } 3 \text { Feb. }\end{array}$ & $\begin{array}{l}28 \\
21 \\
17 \\
10 \\
21\end{array}$ & $\begin{array}{l}37 \\
23 \\
23 \\
22 \\
11\end{array}$ & $\begin{array}{l}-62 \\
-41 \\
-37 \\
-29 \\
-29\end{array}$ & $\begin{array}{l}600 \\
596\end{array}$ \\
\hline
\end{tabular}

reported that weight loss leads to a significant decrease in the proportion of protein in the carcass. Mature sheep (Keenan \& McManus, 1969), which ate during 4 weeks one-third of the amount of food required to maintain body-weight, lost $16 \%$ of their weight, largely owing to loss of protein. Later, the losses were rapidly recovered by offering food ad lib. During $66 \mathrm{~d}$ of semi-starvation (Butterfield, 1966) steers lost $20.9 \%$ dissectable muscle and $15.7 \%$ body-weight; $207 \mathrm{~d}$ recovery allowed increases of $40.9 \%$ and $42.6 \%$ in the percentage of live weight and dissectable muscle respectively.

The $\mathrm{N}$ repletion-depletion capacity is related to the fact that dietary $\mathrm{N}$ regulates the ability to synthesize protein (Wannemacher, Cooper \& Yatvin, 1968). Our results show that the $\mathrm{N}$ digestibility is not affected by protein stores.

When changing the diet, the adjustment of faecal and urinary $\mathrm{N}$ losses depends on the nature of the change. When energy and $\mathrm{N}$ intakes are abruptly increased ('Table 4) urinary excretion is immediately adjusted, while faecal $\mathrm{N}$ increases only gradually.

In simple-stomached animals and lambs the provision of protein-free diets induces a rapid decrease in the urinary excretion of N (Kosterlitz \& Campbell, 1945; Munro, 1964; Walker \& Faichney, 1964; Allison \& Wannemacher, 1965; Gopalan \& Nasaringa Rao, ig66). Our results (Table 8) show a similar effect in the cow. However, faecal $\mathrm{N}$ decreases much less because, when eating a protein-free diet instead of fasting, the ingested dry matter induces endogenous $\mathrm{N}$ losses in the faeces.

Food restriction and fasting have opposite effects to the provision of a low- $\mathrm{N}$ diet (Tables $\mathrm{I}, 5,7$ ); faecal excretion of $\mathrm{N}$ decreases rapidly, while urinary losses remain 
high for several days and often even increase. The results show that the greater the $\mathrm{N}$ and energy intakes before fasting, and thus the protein reserves, the greater the urinary losses during the first few days of fasting. The total $\mathrm{N}$ losses are higher when fasting than when eating a protein-free diet. Similar conclusions were also obtained from experiments on rats (Allison, I964; Allison \& Wannemacher, I965).

The concept, promoted by Allison and his collaborators, of large protein reserves including a very labile part can thus also be applied to the cow. The very labile part of reserves is composed of recently synthesized protein (Fritz, 1956); it is related to the previous nutritional status and may be utilized during starvation. Its more rapid loss when fasting than when eating a low-protein diet shows that this part of the protein reserves allows the cow to meet energy requirements rapidly when dietary energy supply is abruptly removed.

The protein reserves are distributed not only in the liver and viscera but throughout a number of tissues (Allison, 1964; Allison \& Wannemacher, 1965) and especially in muscle; indeed lambs lose protein from their carcass after only $2 \mathrm{~d}$ of fasting (Kirton, Quartermain, Uljee, Carter \& Pickering, 1968).

This work was supported by L'Institut pour l'Encouragement de la Recherche Scientifique dans l'Industrie et l'Agriculture, Brussels.

\section{REFERENCES}

Agricultural Research Council (1965). The Nutrient Requirements of Farm Livestock. No. 2. Ruminants. London: Agricultural Research Council.

Allison, J. B. (1964). In Mammalian Protein Metabolism Vol. 2, p. 4I [H. N. Munro and J. B. Allison, editors]. New York and London: Academic Press.

Allison, J. B. \& Wannemacher, R. W. Jr (1965). Am. F. clin. Nutr. 16, 445.

Allison, J. B., Wannemacher, R. W. Jr, Banks, W. L. Jr \& Wunner, W. H. (1964). F. Nutr. 84, 383.

Association of Official Agricultural Chemists ( 1965$)$. Official Methods of Analysis. Washington, DC: Association of Official Agricultural Chemists.

Butterfield, R. M. (1966). Res, vet. Sci. 7, 168.

De Baere, R., Paquay, R. \& Lousse, A. (1966). Annls Méd. vét. Iro, 8I.

Fisher, H., Grun, J., Shapiro, R. \& Ashley, J. (r964). F. Nutr. 83, 165.

Fritz, I. (1956). Endocrinology 58, 493.

Gopalan, C. \& Nasaringa Rao, B. S. (1966). F. Nutr. 90, 2 г 3.

Kcenan, D. M. \& McManus, W. R. (r969). F. agric. Sci., Camb. 72, I39.

Kellner, O. \& Becker, M. (1962). Grundzüge der Fütterungslehre r 3 th ed. Hamburg and Berlin: Verlag Paul Parey.

Kirton A. H., Quartermain, A. R., Uljee, A. E., Carter, W. A. \& Pickering, F. S. (1968). N.Z. Il agric. Res. $\mathbf{1}, 89 \mathrm{I}$.

Kosterlitz, H. W. \& Campbell, R. M. (1945). F. Physiol., Lond. ro4, i6 P.

Munro, H. N. (1964). In Mammalian Protein Metabolism Vol. I, p. 38I [H. N. Munro and J. B. Allison, editors]. New York and London: Academic Press.

Paquay, R. (1968). Les réserves azotécs chez les bovins et les facteurs alimentaires qui les influencent. Dr. Sci. Agron. Thesis, Université Catholique de Louvain.

Paquay, R., De Baere, R. \& Lousse, A. (1967). Annls Méd. vét. IIr, 84.

Robinson, D. W. (1965). Br. vet. $\mathcal{F}$. 121, 350 .

Seebeck, R. M. \& Tulloh, N. M. (1969). Aust.F. agric. Res. 20, I99.

Voit, C. (1866). Z. Biol. 2, 307.

Walker, D. M. \& Cook, L. J. (I967). Br. F. Nutr. 21, 237.

Walker, D. M. \& Faichney, G. J. (1964). Br. F. Nutr. 18, I87.

Wannemacher, R. W., Cooper, W. K. \& Yatvin, M. B. (1968). Biochem. \%. 107, 6I 5. 